\title{
Attaining Global Relevance through Cutting-Edge Competitive Strategies: A Case Study of Babcock University
}

\author{
Alarape, A. A. ${ }^{1}$ Ogunniran O. $\mathrm{O}^{2} \quad$ Omoba, F. A. ${ }^{3}$ \\ 1.Department of Educational Technology and Library Studies, Obafemi Awolowo University, Ile-Ife \\ 2. Department of Library and Information Science, Adeleke University, Ede \\ 3. Hezekiah Oluwasanmi Library, Obafemi Awolowo University, Ile-Ife
}

\begin{abstract}
The study examined the effectiveness of competitive strategies adopted by Babcock University in response to demand for qualitative higher education. The study employs a descriptive research design and involving a population comprising of employees of Babcock University at the main campus, in Ilishan Remo, Ogun State. Structured questionnaires were administered to 60 respondents selected using stratified sampling technique. Data was analysed in form of frequencies and percentages and presented in form of tables and graphs. The study found that Babcock University uses different competitive strategies. Among these include the combination strategy, cost leadership strategy, differentiation strategy, and focus strategy. It was discovered that the main source of competition for Babcock University is international forces (universities outside the country). The study also found that Babcock University possesses various strategic advantages that make it survive in the market or compete favourably against other Universities both public and private within and outside the country. The research established that Babcock University is exposed to opportunities that would enable it to compete favourably against other universities in future. The study found that Babcock University makes organizational changes that make it to remain competitive in the educational Industry in Nigeria. Babcock University is faced with many challenges in the implementation of her competitive strategies. The researchers recommend that through the effective use of TOWS Matrix, Babcock University can ensure that her activities are more feasible and efficient even within the international arena through the proper identification and optimal use of resources.
\end{abstract}

Keywords: Private University, Babcock University, Strategy, Competitive Advantage, Performance

DOI: $10.7176 / \mathrm{JEP} / 12-22-01$

Publication date:August $31^{\text {st }} 2021$

\section{Introduction}

Private Universities in Nigeria are facing stiff competition necessitating the design of competitive strategies to guarantee their performance and increase confidence of their patrons and customers. This study assesses the effectiveness of competitive strategies adopted by Babcock University in response to demand for qualitative higher education. Today's Educational Industry has gone beyond the armchair era where the managers wait for customers to transact business. Educational Industry operates in a very competitive environment in which they have to be unique in the provision of services to be able to retain their customers' patronage. The true business of every company, private universities inclusive, is to acquire customers, retain them and maximize investors' profitability. Notwithstanding the dismal state of higher educational institutions in Nigeria, there are still some that can stand with their shoulder high when qualitative and quantitative educational services matter. Babcock University is one of such, the very first private higher institution of learning. Babcock University, the first private University was given license to operate as a full fledge university in the year 1999. Since the birth of this first among the equal in the category of private universities, her services, innovation, continuity and the edge she command is the talk of town that warranted even some institutions that have been established decades ago to even borrow leaves from her innovations.

Although the various ranking reports of Higher Educational institutions serve as an indication that Universities must strive to gain increased profile within its industry, government circles and the society, the rapidly changing environments are indications that universities should fully utilize self reports and assessments to remain relevant and become prosperous in the future It must also be emphasized that the competitiveness of universities will not depend only on the individual effectiveness of each university, but even on other industries and the entire socioeconomic system or environment of the host Nation. With this changing global environment, Higher Educational Institutions need to remain or become competitive. Individual Institutions need to optimize the use of their strengths and opportunities in light of the weaknesses and threats faced. One may however want to know the reasons for Babcock University's survival and its prosperity despite the economic crunch that exist in the country. With such situation, one will assume that every Nigerian University should be concerned with competing effectively both locally and globally.

\section{Research Objectives}

This research was set out to achieve the following objectives: 
i. $\quad$ to investigate competitive strategies used by Babcock University;

ii. $\quad$ to establish the sources of competition for Babcock University;

iii. $\quad$ to assess the sources of strength to Babcock University; and

iv. to determine the challenges Babcock University face in attaining edge cutting competitive status.

\section{Research Questions}

This research answered the following questions:

i. What are the Competitive strategies applied by Babcock University?

ii. What are the sources of competition for Babcock University?

iii. What are the sources of strength for Babcock University?

iv. What are the challenges Babcock University faces in attaining edge cutting competitive status?

\section{Literature Review}

Universities within and outside Nigeria are competing with other Higher Educational Institutions globally but many of these universities appear not to have recognized this. This competition is evident in the various rankings and perceptions printed in different world class publications where universities are ranked by indicators of teaching and research performance, their alumni and staff winning Nobel prizes and field medals, highly cited researchers, articles\# published in Nature and Science, articles indexed in major citation indices and the per capita academic performance. Even the research output from universities forms an important index for ranking them internationally (Okebukola 2004; Centre for World Class Universities, 2008). In Nigeria just like other developing countries where the dismal state of higher education institutions is a topical issue, one may want to know the reasons for a university's survival and its prosperity despite the shortcomings that exist within it and its larger environment. With such a situation, one will assume that every Nigerian University should be concerned with competing effectively both locally and globally.

Although the various rankings of Higher Educational institutions serve as an indication that Universities must strive to gain increased profile within the industry, government circles and the society. The rapidly changing environments are indications that universities should fully utilize self reports and assessments to remain relevant and become prosperous in the future (Balderson 1995). It must also be emphasized that the competitiveness of universities will not depend only on the individual effectiveness of each university, but even on other industries and the entire socioeconomic system or environment of the host Nation. With this changing global environment, Higher Educational Institutions need to remain or become competitive. Individual Institutions need to optimize the use of their strengths and opportunities in light of the weaknesses and threats faced. This situational analysis of Babcock University has been implemented using a systematic analysis of the weaknesses and strengths of this University which, operates within the industry that poses threats but also provides opportunities.

With increasing globalization of higher education and competition, universities are forced to equip themselves with the necessary information that would enable them to face the challenges of an international market for higher education (Binsardi \& Ekwulugo, 2003). This innovation can be premised on the assumption that no single organization can ever control or dominate all in effective operating practices and good ideas. Thus, for any higher education institution to become competitive, it must look inward as well as outward for continuous improvement and new ideas. Traditional methods of setting targets seem likely to have failed in Nigerian higher education institutions as it has blinded them to competition. Furthermore, only a few criteria to be highly used for ranking are currently been pursued by Nigerian Universities, so it will be futile to evaluate them with world standards.

Uchechi (2011), Obijiofor (2012, and Oyedotun (2012) opined that competition can become beneficial in education as it has been in manufacturing and commerce. Competition is seen as rivalry process in supplying or acquiring an economic good or service, where sellers compete with other sellers; buyers do the same with other buyers. In this case, each educational institution will form an economic check on others as its competitors (Oplatka, 2002, and Sennholz, 2003). Competitiveness of Universities have been tested by various global ranking systems. Such systems are guided by various perceptions and indeed their reputation. So far, ranking among the higher education institutions is predicted on a number of critical issues such as recognition conferred by national and international bodies, the number of research grants received, their products and findings, the number of patients and products commercialized, the ratio of staff to students, the number of programmes accredited by professional bodies and facilities that meet safety and quality standards. (Okebukola 2004, Centre for World Class Universities, 2008, and Koh, 2012).

As most Higher Education Institutions now aim at excellence in service, competitiveness and quality are arguably the most important evaluation a university employs to enable all of its core activities of teaching, research, community and socioeconomic services to be optimally achieved. Universities should be able to test their strategies and gather information in order to make informed decisions. Good analysis and choices ensure 
the exploitation of opportunities, the avoidance of failure and improved reputation. Universities that seek to be top ranked among other global higher education institutions must be able to identify, compare risks and opportunities against that of other top ranked Universities, their competitors. Such analyses should be regular especially with the constantly changing global environments to provide comprehensive knowledge of current and future higher education industry behaviour. The information gathered from regular analysis are then marched against key performance indicators to enable such universities to effectively position, strategize, monitor and adjust to varying industry conditions, resolve detected challenges as well as take advantage of identified opportunities (NUC 2005, Watson, 2000).

Each University's management will need to assess their ability to draw on two sets of information; information on their current performance and resource position gathered in an internal position assessment; information on the present learning environment and how this is likely to change over the period of the strategy. All this information will be collected by a process of internal/external environmental analysis and competitor analysis. With the range of analytical techniques already developed by the Competitive Intelligence industry, such as benchmarking, personality profiling, gap analysis, war games and business simulations such as SWOT analysis (Strengths, Weaknesses, Opportunities and Threats) and TOWS matrix, a lot of options are currently open to the Nigerian Universities. In-depth knowledge of competitors' near-term tactical moves, strengths, weaknesses, opportunities, possible operating environment changes and price reduction propensities will enable a university's management to put in place appropriate strategies for outsmarting other competitors. (Simmer, 2001, Bobola, 2007).

Placing any University in a competitive situation without sufficient knowledge of rivalries in the industry is strategically dangerous. Such a university will not have key information on new education innovations, its own relative internal strengths and weaknesses, competitors' strategic moves since it has not monitored or analyzed the operations of other competing universities. Thus, such a university is already poorly-equipped to compose and deploy competitive strategies, and will likely lose out in such competition. This creates situations where university management take misleading decisions that definitely cannot give a competitive edge. Also, essential information required for innovating strategies that could result in achieving competitiveness is not readily available and as such having key information on other competitors' likely future tactics is very important. (Kalvermark \& Wende, 1997, Mazzarol \& Soutar, 1999, Czarniawska \& Genell, 2002, Ronquilo, 2012).

In the educational sector, increased competition threatens the attractiveness of the industry and reduces the profitability of the players in the sector. It exerts pressure on universities to be proactive and to formulate successful strategies that facilitate proactive responses to anticipated and actual changes in the competitive environment (Johnson \& Scholes, 2002). Educational institutions therefore focus on gaining education institution competitive advantage to enable them respond to, and compete effectively in the market. By identifying their core competences, private universities are able to concentrate on areas that give them a lead over competitors, and provide a competitive advantage (Pearce \&Robinson, 2005). According to Johnson and Scholes (2008), core competences are more robust and difficult to imitate because they relate to the management of linkages within the organization's value chain and to linkages into the supply and distribution chains.

Porter (2004) viewed competitive strategies as a two-dimensional phenomenon with a supply side strategic scope; and a demand side - strategic strength. He later simplified the scheme into three generic strategies, namely 'overall cost leadership', 'differentiation' and 'focus'. Johnson, Scholes and Wittington (2008) on the other hand, perceive competitive strategies from a business level perspective and believe that it is the achievement of competitive advantage by a business unit in its particular market. They advocate for a hybrid strategy which provides a market-facing element to Porter's model in the form of price as a new dimension and its combination with differentiation. Sidorwicz (2007) on the other hand sees competitive strategies as more skill-based and involving strategic thinking, innovation, execution, critical thinking, positioning and the art of warfare. Drucker (2008) noted that management is primarily about the continuing development of the organization and its employees. The demands and needs of the environment are constantly evolving and management is about adjusting the company according to the needs and demands of the environment. One of the environmental influences to a business normally arises from competition (Pearce \& Robinson, 2005). To sail above the storm of competition, there is need for combined strategies.

Combined strategy of an organization involves matching its corporate objectives and its available resources effectively and efficiently. In this development of strategy, managers are concerned with reconciling the business or organization in the allocation of resources (Porter, 2004). This allocation process is concerned with the general purposes of an organization, whether it is part of the grand plan, the overall objectives or a 'strategy' designed to keep the organization in business (Hannagan \& Bennett, 2008). According to Drucker, (2001) strategy is the pattern of major objectives, purposes or goals and essential policies or plans for achieving these goals, stated in such a way as to define what business the company is in or to be in and the kind of company it is or is to be. The researchers intend to carry out a survey that will assess the effectiveness of the competitive strategies adopted by Babcock University, in response to demand for qualitative educational services in Nigeria. 


\section{Theoretical Framework}

The study is hinged on Porter's five forces theory. According to porter's five forces theory the competitive strategy must grow out of a sophisticated understanding of the rules of competition that determine an industry's attractiveness. The ultimate aim of competitive strategy is to cope with and, ideally, to change those rules in the firm's behaviour. The five forces determine industry profitability, and some industries may be more attractive than others. The crucial question in determining profitability is how much value firms can create for their buyers, and how much of this value will be captured or computed away. Industry structure determines who will capture the value. But a firm is not a complete prisoner of industry structure; firms can influence the five forces through their own strategies. The five forces highlight what is important, and direct managers towards those aspects most important to long term advantage (Porter, 2002). Hall and Saias (1980) investigated sixty-four American companies and the findings of the study revealed that companies following a differentiation strategy had superior performance compared to those companies that were not following the same. It is important for analysts to note that there is more than one way in which a company can make use of differentiation. Differentiation can be achieved through a differentiated product, superior quality, and customer service etc. A key question to ask is whether the customers of the company perceive the point of difference as one that is worth a price premium. Chan and Jamison (2001) carried out an investigative study on the competitive strategies applied by banks in China from 1978 to1998. The author states that the sector witnessed important players' going in and out, different legal regulations were fulfilled, the structure and intensity of the competition became different, and trade making/differentiation became the most important element of the competition in that period.

Bonaccorsi di Patti and Gobbi (2001) carried out a study on the effect of competition on commercial banks in Italy. They sampled 15 commercial banks in Rome. From their study they found that competition leads to higher growth rates and greater access to credit by new firms and other SMEs. However, they found that competition has unfavourable effects including less new firm creation, expansion, and employment, less economic growth and slower exit of mature firms. Ferdinard (2002) carried out a study on the competitive strategies applied by Tesco Company in the UK. This study was carried on 230 employees in the various departments of the company. He noted that the company was positioned to capitalize on a value proposition which emerged from their low-cost emphasis. They also found that the company typically focused their efforts on value-oriented customers in the market. Value products are focused on providing value-oriented customers with products that are indeed value-for-money, relative to competitive offerings.

Carletti and Hartmann (2003) carried out a survey of 231 MFIs in London on effect of competition on financial stability. They found that the degree of competition in the financial sector can matter for the access of firms and households to financial services and external financing, in turn affecting overall economic growth. Alamdari and Fagan (2005) carried a model-based study, by discussing the effectiveness of the lowcost model and the effect on the profitability of banks. They found that the bank with the lowest costs would earn the highest profits in the event when the competing products are essentially undifferentiated, and selling at a standard market price. Companies following this strategy place emphasis on cost reduction in every activity in the value chain. They however found that the company's focus on reducing costs, even sometimes at the expense of other vital factors, may become so dominant that the company loses vision of why it embarked on one such strategy in the first place. A study on Ghana by Mathisen and Buchs (2005) used the Panzar-Rosse framework in determining the degree of competition in the Ghanaian banking sector. In their study, two reduced-form revenue equations are estimated; one for total (including interest) revenue scaled using total assets and the other for unscaled total (including interest) revenue. The explanatory variables used for this study are the three-dimensional vector of factor prices; namely the ratio of personnel expenses over total loans and deposits, the ratio of interest expense over total deposits, and the ratio of other operating and administrative expenses over fixed assets.

\section{Methodology}

This study employed descriptive research design as a process of collecting data in order to answer questions concerning the competitive strategies of Babcock University. The study population consists of staff of Babcock University (Faculty and administrative). The study sampled 60 respondents selected using stratified sampling technique. A structured questionnaire was used for data collection. The questionnaire comprised of four (4) main sections based on the four questions the research intends to answer. In order to establish the effectiveness of competitive strategies adopted by Babcock University in response to demand for qualitative higher education services, 60 questionnaires were administered, and 52 questionnaires were received back fully completed representing an $86.7 \%$ response rate. The administered questionnaires were closed-ended. The choice of the instrument was based on the fact that it makes it easier to get adequate and accurate information necessary for the research. Descriptive statistics such as frequencies and percentages, tables and graphical presentations was also adopted in the study. 


\section{Results and Discussion}

7.1Research Question One: What are the Competitive strategies applied by Babcock University?

Table 1: Competitive Strategies Adopted by Babcock University

\begin{tabular}{|l|l|l|}
\hline Competitive Strategies & Frequencies & Percentage \\
\hline Differentiation strategy & 52 & 100 \\
\hline Focus Strategy & 51 & 98 \\
\hline Cost Strategy & 42 & 81 \\
\hline Combination strategy & 48 & 92 \\
\hline
\end{tabular}

Source: Field Work on Babcock University competitive Strategies, 2018

From the findings on the competitive strategies applied by Babcock University in response to demand for qualitative higher education services, the study found that majority of the respondents as shown by $98 \%$ indicated Focus strategy, 100\% indicated Differentiation, $81 \%$ indicated Cost Leadership strategy while 92\% indicated Combination strategy. This is an indication that Babcock University uses all strategies available to attain global relevance and competitive advantages in response to demand for qualitative higher education services.

7.2Research Question Two: What are the Sources of Competition for Babcock University available to Babcock University?

Table 2: Sources of Competition for Babcock University

\begin{tabular}{|l|c|l|}
\hline Forces & Frequency & Percentage \\
\hline Internal forces & 5 & 9.6 \\
\hline External forces & 15 & 28.9 \\
\hline International Forces & 32 & 61.5 \\
\hline Total & $\mathbf{5 2}$ & $\mathbf{1 0 0}$ \\
\hline
\end{tabular}

Source: Field Work on Babcock University competitive Strategies, 2014

The study found that majority of the respondents as shown by $61 \%$ indicated the major source of competitive forces as International followed by external forces which are $28.9 \%$. This is an indication that the main source of competition for Babcock University is international forces. The other noticeable source of competition is external forces with $28.9 \%$.

7.3Research Question Three: What are the Sources of Strengths available to Babcock University on the field of education?

Table 3: Sources of Strengths to Babcock University

\begin{tabular}{|l|c|c|}
\hline Sources of Strength & Frequency & Percentage \\
\hline Long tradition in the industry & 52 & 100 \\
\hline High quality services & 51 & 98.1 \\
\hline Good service engineering & 50 & 96.2 \\
\hline Good customer reputation & 49 & 94.2 \\
\hline Strong marketing abilities & 51 & 98.1 \\
\hline Market research capability & 51 & 98.1 \\
\hline Launch of highly differentiated services & 45 & 86.5 \\
\hline Growing importance of higher degrees to the customers & 44 & 84.6 \\
\hline
\end{tabular}

Source: Field Work on Babcock University competitive Strategies, 2018

The table showed the strengths that Babcock University possesses that make her have competitive advantage or survive in the market or compete favourably against other universities in the country. The study found that majority of the respondents, $100 \%$ indicated long tradition in the industry, $98.1 \%$ indicated high quality services, Market research capability and strong marketing abilities as the key to the strength of Babcock University competitive status. 96.2\% indicated good service engineering, $94.2 \%$ indicated good customer reputation, $86.5 \%$ indicated Launch of highly differentiated services and $84.6 \%$ indicated growing importance of higher degree to the customers. The above strength no doubt enables the university to have in-depth knowledge of competitors' near-term tactical moves, strengths, weaknesses, opportunities, possible operating environment changes and price reduction propensities that enable the university's management to put in place appropriate strategies for outsmarting other competitors.

7.4Research Question Four: What are the Challenges Babcock University Faces in Implementing her Competitive Strategies on the field of education? 
Table 4: Challenges Babcock University Faces in implementing her Competitive Strategies

\begin{tabular}{|l|c|c|}
\hline Challenges & Frequencies & Percentage \\
\hline Steve competition within and outside the country & 51 & $98.1 \%$ \\
\hline Rise in costs associated with administration & 48 & $92.3 \%$ \\
\hline Rise in costs associated with services & 46 & $88.5 \%$ \\
\hline Complexity in needs of customers & 35 & $67.3 \%$ \\
\hline
\end{tabular}

Source: Field Work on Babcock University competitive Strategies, 2018

From table 4, the study found that most of the respondents agreed that Babcock University major challenge is Steve competition within and outside the country with $98.1 \%$, follow by Rise in costs associated with administration with $92.3 \%$, Rise in costs associated with our services with $88.5 \%$, and Complexity in needs of customers $67.3 \%$.

\section{Conclusions}

Given the foregoing analogies, the study concludes that Babcock University applies different strategies in response to demand for quantitative and qualitative educational services with the major strategies applied being a combination strategy, cost leadership strategy, differentiation strategy, and the focus strategy. Secondly, there are three sources of competitive forces in the educational industry and these were international, external and internal forces as the firms fight for the market share and improved customer service. Thirdly, Babcock University have different sources of competitive advantage or strengths or opportunities that put her above other universities in the Nigerian educational industry. Such potentials may be anchored on long educational tradition, high quality services, Market research capability and strong marketing abilities as the key to the strength of Babcock University competitive status. Other sources of strength include but not limited to good service engineering, good customer reputation, and launch of highly differentiated services and growing importance of higher degree to the customers.

\section{Recommendations}

In light of the obvious threats and the opportunities identified by this study including also the weaknesses and internal strengths, various strategies should be considered if Babcock University is to remain competitive. A strategy that holds the right potential for Babcock University involves using their strengths to take advantage of available opportunities, not only locally, but also globally. Through the use of TOWS Matrix, Babcock University can ensure that her activities are more feasible and efficient even within the international arena through the proper identification and optimal use of resources. The use of TOWS Matrix Methodology highlights aspects of Babcock University that have significant impact positively and points out the Social, Economic, Political, and Technological factors to be considered in promoting the University's strengths and reduce to the minimum what could serve as her weaknesses. This study signals present conditions, external opportunities for possible exploitation while threats to the university are also analysed.

\section{References}

Alamdari, F., \& Fagan, S. (2005). "Impact of the Adherence to the Original Low - Cost model on the Profitability of Low - Cost Airlines" Transport Reviews, 25(3), 377-392.

Bonaccorsi di Patti, E., \& Gobbi, G. (2001). "The Changing Structure of Local Credit Markets: Are Small Businesses Special"? Journal of Banking \& Finance, 25(12), 2209-2237.

Binsardi, I., \& Ekwulugo, F. (2003). "International Marketing of British Education: Research on the students' perception and the UK market penetration. Marketing Intelligence \& Planning", 21(5), 318-327. http://dx.doi.org/10.1108/02634500310490265. Accessed on 25/4/2015.

Bobola, A. (2011). "Strategic Management in the Nigerian University System". In Administration of Education; A Professional Perspective (p. 21). Akure, Ondo: Flocel.

Carletti, E., \& Hartmann, P. (2003). Competition and stability: What's special about banking. Monetary history, exchanges rates and financial markets: Essays in honour of Charles Goodhart, 2, 202-229.

Chan-Olmsted, S., \& Jamison, M. (2001). "Rivalry through alliances: Competitive Strategy in the Global Telecommunications Market". European Management Journal, 19(3), 317-331.

Drucker, P. F. (2008). "Management Consultant", Zimmer, M. \& Smiddy, H. The Evolving Science of Management. New York: AMACOM.

Dabrowski, R. (2009, June 9). Integrity and Spirituality Hallmarks of Babcock University, statesmen say. Nigeria's Adventist University commended for exemplary Educational Standards. Adventist News Network.http://news.adventist.org/all-news/news/go/2009-06-09/nigerias-adventist-university-commen dedfor-exemplary-educational-standards/

Hall, D. J., \& Saias, M. A. (1980). “Strategy follows structure!”. Strategic Management Journal, 1(2), 149-163. 
Hannagan, T., \& Bennett, R. (2008). Management: concepts \& practices. Pearson Education.

Johnson, G., Scholes, K., \& Whittington, R. (2008). Exploring corporate strategy: text \& cases.

Pearson Education.

Hemsley-Brown J.V. \& Oplatka, I. (2006). "Universities in a Competitive Global Marketplace: A Systematic Review of The Literature on Higher Education Marketing" International Journal of Public Sector Management, 19(4), 313-338.

Koh, K. (Director) (2012, June 30). Enhancing University Competitiveness through Educational Facilities. Keynote Speech. Lecture conducted from Ministry of Education, Science and Technology, Korea.

Makinde, J. K. (2012, June 3). This far by activated faith. 10th Convocation President's Address. Lecture conducted from Babcock University, Ilishan-Remo.

Mazzarol, T., \& Soutar, G. (1999). "Sustainable competitive advantage for educational institutions: A suggested model". International Journal of Educational Management, 12(6), 287-300. http://dx.doi.org/10.1108/09513549910294496

Nigerian Universities Commission. (2005). Formulation of a Strategic Plan. In Manual on Strategic Planning for Nigerian Universities and Inter - University Centers (pp. 6-7). Garki, Abuja: Nigeria Universities Commission.

Ngechu, M. (2004). Understanding the research process and methods. An introduction to research methods.

Obijiofor, L. (2012, February 3). "Jonathan's false tears over low Varsity Ranking”. Guardian Newspaper. http://odili.net/news/source/2012/feb/3/22.html

Oplatka, I. (2002). "Implicit contradictions in public messages of 'low-stratified' HE institutions: The case of Israeli teacher training colleges". The International Journal of Educational Management, 16(5), 248-256.

Oyedotun, A. (2012, April 16). "Why our Varsities are rated poor". Tell Magazine, 60-60.

Pearce, J. A., \& Robinson, R. B. (2000). Strategic management: Formulation, implementation, andcontrol. Irwin/McGraw-Hill.

Poter, M. E. (2004). Competitive strategy: techniques for analyzing industries and competitors. Free press.

Sidorowicz, R. (2007). Competitive strategy. Toronto, Refresher Publications Inc.

Sennholz, H.F (2003). Competition and Higher Education. Mises Daily. http://mises.org/library/competition-andhigher-education

Simmer, R. (2001). Using Intellectual Property Data for Competitive Intelligence. Intellectual Asset Management and Technology Commercialization, 6-6 http://patex.ca/pdf/publications/CH4CompIntelRevB.pdf

Watson, D. (2000). Managing Strategy. In Managing Universities and Colleges: Guides to Good Practice. Buckingham: Open University Press. 